\title{
The Influence of Pedagogic Competency, Leadership of Schools, and Work Motivation Towards Teacher Performance in State Elementary Schools in Medan City
}

\author{
Elly Romy', Muhammad Ardansyah'2, \& Hambali*3 \\ ${ }^{1}$ Doctoral in Educational Management, State University of Medan, Medan, Indonesia \\ 2 Universitas Potensi Utama Medan, Medan, Indonesia \\ ${ }^{3}$ Department of Primary School Teacher Education, Serambi Mekkah University, Banda Aceh, Indonesia \\ ellyromy268@gmail.com; ardansyah.2011@gmail.com; hambali_nurin@yahoo.com \\ *Corresponding Author: hambali_nurin@yahoo.com | Phone Number: +6281360889491
}

Received: 25 February 2021

Revised: 12 March 2021

Accepted: 10 April 2021

\begin{abstract}
Teacher performance is the result of work achieved when planning, implementing, and assessing learning in schools. The results showed: (1) the effect of pedagogic competence on the work motivation of public elementary school teachers in the Medan City is 0.242 ; (2) the influence of the principal's leadership on the work motivation of State elementary school teachers in the Medan City is 0.238; (3) the influence of pedagogical competence on the performance of public elementary school teachers in the Medan City is 0.259 ; (4) the influence of principal leadership on the performance of public elementary school teachers in the Medan City is 0.207; and (5) the effect of work motivation on the performance of public elementary school teachers in the Medan City is 0.200. Based on the results of the study, it was found that the pedagogic competence, principal leadership, and work motivation on teacher performance was $28.7 \%$ and the rest was determined by other circumstances.
\end{abstract}

Keywords: pedagogic competence; principal leadership; work motivation; teacher performance;

\section{Introduction}

Elementary school is a basic education institution that functions to in still values, attitudes, and a sense of beauty, as well as to provide basic knowledge and ability to read, write, and observe for students so that they have provisions to continue their education at the next level. In other words, the purpose of primary school education is to lay the foundation for intelligence, knowledge, personality, noble character, and skills to live independently and follow further education. In this connection, elementary schools carry three missions, namely carrying out the education process, the socialization process, and the transformation process (Bafadal, 2006:20). The achievement of these three missions places teachers as the main component of education. Teachers in the context of education are related to the professions they carry as educators and teachers for students at various levels of education. Priansa (2014:35) suggested that the teacher is the main facilitator in the school whose function is to explore, develop, and optimize the potential of students so that they can become part of a civilized and advanced society. This strategic role is stated in Law Number 14 of 2005 concerning teachers and lecturers, which places the position of teachers as professionals as well as as facilitators, motivators, stimulators, learning engineers, and learning inspirations for students. This role requires teachers to be able to improve the resulting performance in line with changes and demands that arise from society for the world of education.

Initial observations of researchers at the Medan City Education Office in December 2020 can be seen that the performance of teachers at these schools is still not good. Information on elementary school supervisors in Medan, obtained information about the performance of elementary school teachers in Medan, including: (1) there are still many teachers who have not been able to create good learning conditions in the classroom, so that students appear less active in learning. Of the 20 teachers observed, the supervisor saw that only 5 teachers were able to build conducive learning conditions/support learning in the classroom, the rest directly provided material without trying to create learning conditions that supported learning; (2) many teachers only use the lecture method and take notes in front of the class. Of the 20 people observed, only 8 were seen to be using various methods and inviting students to take an active role in learning in class; and 
(3) almost none of the 20 teachers were observed to provide feedback on the results of homework that students have completed. The teacher only checks and gives grades without asking and explains the weaknesses of students in completing their homework. This condition indicates that the teacher does not work well in classroom learning. For that, it is necessary to improve teacher performance in primary schools. One of them is by examining various factors that may influence teacher performance in schools. From the observations it was also found that many teachers (around 60\%) taught with makeshift materials and teachers only used material in textbooks. In addition, elementary school supervisors also explained the poor performance conditions of teachers, including: (1) elementary school teachers in Medan City still use conventional teaching methods; (2) the teacher only uses the subject matter in the book, does not provide additional new knowledge; (3) teachers do not encourage students to generate new creative ideas; (4) teachers seem lazy to develop new knowledge in the community for classroom learning materials; and (5) not prioritizing creative attitudes in classroom learning.

Teacher performance is basically the performance or work achieved by the teacher in a certain period. In general, performance is influenced by several components, namely individual mechanisms, individual characteristics, group mechanisms, and organizational mechanisms (Setiawan et al, 2020; Lutfah, 2019; \& Hambali et al, 2020). Colquitt, et al (2015: 9) declare that: A number of factors affect performance and commitment, including individual mechanisms (job satisfaction, stress, motivation, trust, justice and etics, learning and decision making), individual characteristics (personality and cultures values, ability), group mechanisms (team characteristics, team processes, leader power and influence, leader style and behaviours), and organizational mechanisms (organizational structure, organizational culture). Gibson et al (2007: 14) argues about three sets of variables that affect performance or job performance. According to Gibson, performance is a measurement tool for management that is used to assess the level of a person's acobserveability in carrying out their duties. Based on Gibson's study, that work performance or performance is the impact of the influence of the three variables, namely: individual variables, which include abilities and skills, physical and mental, background, experience and demographics, age, gender, origin and so on. Ability and skills are the main factors that influence individual performance, while demographics have an indirect relationship to behavior and performance. Age is closely related to a person's level of maturity.

The success of achieving a goal cannot be separated from the teacher's performance. From the results of preliminary observations, it can be seen that there are still teachers who arrive not on time, an indication that a study of the work motivation of teachers at the Medan City Education Office is still necessary. This study is deemed necessary because undue motivation can reduce teacher performance either partially or as a whole as a system. Another indication, there are still work completion that is not on time due to ineffective teacher performance. Looking at these problems, in this study to solve the problem of not optimal performance, an organizational behavior approach will be used. Robbins (2008: 10) stated organizational behavior is a study that studies the impact of individuals, groups and structures on behavior in organizations with the intention of such knowledge to improve organizational effectiveness. As a social behavior, individual performance is certainly influenced by many factors. Therefore, this study is directed to examine the factors that can affect the performance of primary schools $\mathrm{M}$, namely leadership factors and motivation factors.

The increase in teacher performance is influenced by work motivation which is directed at achieving its goals at work (Simorangkir et al, 2019; Rahayu et al, 2019; Siagian \& Sirait, 2019). Work motivation becomes a motivation for someone to carry out an activity in order to get the best results (Wahyuningtyas et al, 2020; Tanjung et al, 2020; \& Puspandhani et al, 2020). Therefore, it is not surprising that teachers who have high work motivation will show good performance. The results of research by Samson (2006) and Siwantara (2009) state that work motivation affects one's performance. Winardi (2002: 6) argues that work motivation is a potential strength that exists in a human being, which can be developed by a number of outside forces which essentially revolve around monetary rewards and non-monetary rewards that can affect the results of their performance positively or negatively, which depends on the situation and conditions faced by the person concerned.

Several previous studies, such as Kristen et al (2019), found that organizational culture supports citizens' organizational behavior. In addition, motivation also increases due to the influence of culture and organizational behavior in a school (Ridlo et al, 2020). It is also in line with the research of Mashari \& Umami (2019) and Rahman et al (2020) that teacher motivation and teacher characteristics greatly affect student achievement and learning outcomes in schools.

The principal is directly related to administrative staff in providing services to the community. The principal must be able to create a conducive work culture, mutually support one another, streng then the organizational energy to provide optimal service to the community. Thus, the principal is as a leader and manager in his field. According to Birch (2001: 5), as a manager he is more focused on the task, and as a leader, he is more integrated with the people he leads. Thus, one of the characteristics of a great leader is to 
produce something and realize that their success in carrying out their duties is due to the goodwill and support of the people around them. In other words, a principal has a leadership style to foster goodwill and support from his subordinates to be able to provide educational services in accordance with existing standards.

Adequate teacher abilities mean that they will be able to complete their work properly according to the predetermined targets. This means that the teacher must devote all his abilities in carrying out the tasks that are their responsibility. Increasing teacher knowledge in mastery of theory and skills is intended to decide issues related to activities in order to achieve school goals. This certainly increases their ability at work so that teachers can work more effectively in schools in carrying out their duties, sometimes requiring technology assistance. In addition, education and training programs aim to improve teacher ability, efficiency and teacher performance in achieving work goals (Handoko, 2007: 103). Based on the description above, it appears the role of leadership factors, pedagogical competence and work motivation in improving the performance of elementary school teachers. This encourages researchers to conduct research under the title: The Influence of Principal Leadership, Pedagogic Competence, and Work Motivation on the Performance of Public Elementary School Teachers in the Medan City.

\section{Methods}

This research is a quantitative type of path analysis. Riduwan (2008: 2) states that path analysis is used to analyze the pattern of relationships between variables in order to determine the direct or indirect effect of a set of exogenous variables on endogenous variables. The population in this study were 293 public elementary school teachers in Medan City. The research sample is a portion of the population taken as a data source, and can represent the entire population. Determining the number of samples using the Slovin formula obtained as many as 171 people. The sampling technique used is Proposional Random Sampling.

\section{Results and Discussions}

\subsection{Results}

\section{Normality Test}

To find out whether the data for each variable is normally distributed or not, it is necessary to test for normality with the Liliefors test. To accept or reject the null hypothesis, we compare Lo with the critical value of Ltabel for the real level $=5 \%$. The data for each variable is said to be normally distributed if $\mathrm{L}_{\text {observe }}<$ $\mathrm{L}_{\text {table }}=0.05$. Based on Table 1, all endogenous variables based on exogenous variables have a normal distribution, thus the assumption of normality has been fulfilled.

\section{Test of Linearity and Meaning of the Regression Equation}

To test the linearity assumption is carried out based on the linearity test with the F test on the data of each endogenous variable on the exogenous variable. The hypothesis proposed in the linearity test is:

Ho: non-linear regression

Ha: linear regression

The test criteria: reject Ho if the significance of the $F_{\text {observe }}>0.050$ or accept Ho if the significance of the $F_{\text {observe }}$ value $<0.050$. To test the meaning of the regression equation, the proposed hypothesis is:

Ho: regression is not significant

Ha: significant regression

Based on Table 2, the results of the linearity and significance of the regression are obtained:

1 . There is a linear regression direction and means between pedagogic competence $\left(X_{1}\right)$ on work motivation $\left(\mathrm{X}_{3}\right)$ with a value of $\mathrm{Fh}=1.209$ with a significance of $0.285>0.05$; and significant with the value of $\mathrm{Fh}=$ 5.885 with a significance of $0.018<0.05$. Thus, increasing pedagogical competence can optimize the work motivation of elementary school teachers in Medan City.

2. There is a linear and meaningful regression direction between principal leadership $\left(X_{2}\right)$ on work motivation $\left(\mathrm{X}_{3}\right)$ with a value of $\mathrm{Fh}=0.988$ with a significance of $0.506>0.05$; and significant with the value of $\mathrm{Fh}=6.678$ with a significance of $0.013<0.05$. Thus, increasing the leadership of school principals can optimize the work motivation of elementary school teachers in Medan City.

3. There is a linear regression direction and means between pedagogical competence $\left(X_{1}\right)$ on teacher performance $\left(\mathrm{X}_{4}\right)$ with a value of $\mathrm{Fh}=1.252$ with a significance of $0.252>0.05$; and significant with the value of $\mathrm{Fh}=8.167$ with a significance of $0.006<0.05$. Thus, increasing pedagogical competence can optimize the performance of elementary school teachers in Medan City. 
4. There is a linear and meaningful regression direction between principal leadership $\left(\mathrm{X}_{2}\right)$ on teacher performance $\left(\mathrm{X}_{4}\right)$ with a value of $\mathrm{Fh}=1.224$ with a significance of $0.273>0.05$; and significant with the value of $F h=6.882$ with a significance of $0.011<0.05$. Thus, improving the leadership of school principals can optimize the performance of elementary school teachers in Medan City.

5 . There is a linear regression direction and means between work motivation $\left(X_{3}\right)$ on teacher performance $\left(\mathrm{X}_{4}\right)$ with a value of $\mathrm{Fh}=1.044$ with a significance of $0.444>0.05$; and significant with the value of $\mathrm{Fh}=$ 8.314 with a significance of $0.005<0.05$. Thus, increasing work motivation can optimize the performance of elementary school teachers in Medan City.

Table 1. Summary of the Kolmogorov-Smirnov Test Normality Test Results

\begin{tabular}{|c|c|c|c|c|c|}
\hline & & $\begin{array}{c}\text { Pedagogic } \\
\text { Competence }\end{array}$ & $\begin{array}{c}\text { Principal } \\
\text { Leadership }\end{array}$ & Work motivation & Teacher Performance \\
\hline $\mathrm{N}$ & & 171 & 171 & 171 & 171 \\
\hline \multirow[t]{2}{*}{ Normal Parametersa,b } & Mean & 87,41 & 77,86 & 77,39 & 83,63 \\
\hline & Std. Deviation & 9,803 & 13,376 & 9,818 & 11,165 \\
\hline \multirow[t]{3}{*}{ Most Extreme Differences } & Absolute & ,016 & ,038 & ,014 & ,026 \\
\hline & Positive & ,011 & 027 & 014 & 020 \\
\hline & Negative &,- 016 &,- 038 &,- 011 &,- 026 \\
\hline Test Statistic & & ,016 & 038 & ,014 & ,026 \\
\hline Asymp. Sig. (2-tailed) & & 120cd &, $082^{c, d}$ & $124^{\mathrm{c}, \mathrm{d}}$ & $, 097 \mathrm{c}, \mathrm{d}$ \\
\hline
\end{tabular}

Table 2. Summary of Test Results for Linearity and Significance of Regression

\begin{tabular}{|c|c|c|c|c|c|c|c|}
\hline \multirow{2}{*}{ No. } & \multirow{2}{*}{ Variable } & \multicolumn{3}{|c|}{ Test of Linierity } & \multicolumn{3}{|c|}{ Test of Significance of Regression } \\
\hline & & Fh & Sig. & Status & $\mathrm{Fh}$ & Sig. & Status \\
\hline 1 & $X_{1}$ with $X_{3}$ & 1,209 & 285 & Linier & 5,885 & 018 & Significant \\
\hline 2 & $\mathrm{X}_{2}$ with $\mathrm{X}_{3}$ & ,988 &, 506 & Linier & 6,578 & 013 & Significant \\
\hline 3 & $\mathrm{X}_{1}$ with $\mathrm{X}_{4}$ & 1,252 & 252 & Linier & 8,167 & 006 & Significant \\
\hline 4 & $\mathrm{X}_{2}$ with $\mathrm{X}_{4}$ & 1,224 & 273 & Linier & 6,882 & 011 & Significant \\
\hline 5 & $\mathrm{X}_{3}$ with $\mathrm{X}_{4}$ & 1,044 & 444 & Linier & 8,314 & 005 & Significant \\
\hline
\end{tabular}

\subsection{Discussions}

\section{Pedagogic competence has a direct effect on work motivation}

The findings of the study show that the magnitude of the direct influence of pedagogic competence on work motivation is $5.8 \%$. The influence that pedagogic competence provides on work motivation comes from the components of technical skills, human skills, and conceptual skills. In this case, technical skills contributed $32.050 \%$ to pedagogical competence. Human skills contribute $36.142 \%$ to pedagogical competence. Meanwhile, conceptual skills contributed $31.808 \%$ to pedagogical competence.

Based on these results, the pedagogical competence variable is more influenced by the human skill component. The human skills of a leader can determine his leadership for his subordinates. In this case, human skills influence one's leadership in motivating teachers to work. Hoy and Miskel (2001: 198) emphasized that human skills focus on the ability to understand the feelings and attitudes of others and build cooperative working relationships. To be effective, these skills must be exercised naturally, unconsciously, and consistently in a leader's behavior.

The results of this study support the theory put forward by Colquitt, et al (2015: 9) that leadership in organizations has an influence on the work motivation of their subordinates. The results of this study also support Samson's (2006) research that leadership affects the achievement motivation of his subordinates. This illustrates that pedagogical competence affects the work motivation of public elementary school teachers in Medan City.

In addition, it was found that the level of pedagogic competence was relatively moderate (71-91), namely $53.521 \%$. This shows that pedagogical competence still needs to be improved. Stoner (1992: 18) says that human skills are the ability to cooperate, understand, and motivate others as individuals or in groups. Human skills emphasize working with people, which is much different from technical skills which emphasize working with things. Pidarta (2004: 217) says that humanitarian skills are essentially skills to make optimal cooperative contacts with people who are invited to work by paying attention to their nature and dignity as humans. Thoha (2004: 37) says that human skills are the ability to work to understand and motivate others, both as individuals and groups. Managers need these skills in order to gain participation and direct the group to achieve goals. 
Principal leadership has a direct effect on work motivation

The findings of the study show that the magnitude of the direct influence of the principal's leadership on work motivation is $6.7 \%$. The influence given by the principal's leadership on work motivation comes from the components of the level of knowledge about their work, and the level of teacher skills at work. In this case, the level of knowledge about his job contributed $44.193 \%$ to the leadership of the principal. Meanwhile, the level of teacher skills at work contributed $55.807 \%$ to the principal's leadership.

Based on these results, the principal's leadership variable is more influenced by the teacher's skill component at work. The level of work skills of a teacher can determine his ability to work on a day-to-day basis at school. In this case, the level of teacher skills at work affects a person's motivation to continue working. The results of this study support the theory put forward by Colquitt, et al (2009: 8) that a person's principal leadership has an influence on work motivation.

The leadership of the principal is the knowledge and skills of the teacher in doing any work that is their job according to their field of expertise. Every qualified teacher must have good principal leadership. The success and skill of doing work in an organization is very dependent on the performance of the teacher, so that the leadership of the principal is important for a teacher to be able to complete the job well. In addition, it is found that the level of principal leadership tendency is still classified as moderate (68-87), namely as much as $63.380 \%$. This shows that the leadership of the principal still needs to be improved. A person's ability to increase work motivation will be reflected in the knowledge and skills they possess supported by their physical and psychological conditions. Therefore, to carry out a job it is not enough if you only have knowledge and skills, but must also be supported by a strong ability to carry out the job. As a result, through good principal leadership, the organization will succeed in achieving the expected performance levels.

Pedagogic competence has a direct effect on teacher performance

The findings of the study indicate the magnitude of the effect of pedagogic competence directly on teacher performance by $5.7 \%$. The influence that pedagogic competence provides on teacher performance comes from the components of technical skills, human skills, and conceptual skills. In this case, technical skills contributed $32.050 \%$ to pedagogical competence. Human skills contribute $36.142 \%$ to pedagogical competence. Meanwhile, conceptual skills contributed $31.808 \%$ to pedagogical competence.

Based on these results, the pedagogical competence variable is more influenced by the human skill component. The human skills of a leader can determine his leadership for his subordinates. In this case, human skills influence one's leadership in managing and directing subordinates to work well. The results of this study support the research of Sri widodo and Bangun (2007) and Irawati and Bambang (2010) that there is a positive influence of leadership on employee performance.

Pedagogic competence is a pattern of leadership behavior from each principal towards his subordinates in achieving organizational goals. The principal in carrying out his duties must be able to improve teacher performance, both through encouragement (motivation) and by fulfilling teacher needs. When teachers get encouragement and their needs are met, the teacher will do their job as well as possible.

In addition, it was found that the level of pedagogic competence was relatively moderate (71 - 91), namely as much as $53.521 \%$. This shows that pedagogical competence still needs to be improved. A school principal is said to be unsuccessful if he cannot motivate, motivate, and satisfy teachers in working in the organization. Teachers will feel comfortable and excited to work because of the encouragement or motivation given by the principal.

\section{Principal leadership has a direct effect on teacher performance}

The research findings show that the principal's leadership has a direct effect of $4.3 \%$ on teacher performance. The influence of the principal's leadership on teacher performance comes from the components of the level of knowledge about their work, and the level of teacher skills at work. In this case, the level of knowledge about his job contributed $44.193 \%$ to the leadership of the principal. Meanwhile, the level of teacher skills at work contributed $55.807 \%$ to the principal's leadership.

Based on these results, the principal's leadership variable is more influenced by the teacher's skill component at work. The level of work skills of a teacher can determine his ability to work on a day-to-day basis at school. In this case, the level of teacher skills at work affects how a person works in his school. In school organizations, it can be seen that in the placement of teachers or employees, in general, the higher a person's position in the organization, the more needed is high intellectual ability and not physical ability. Regarding a person's ability, it really depends on his physical and psychological condition, which in turn will affect the level of ability to carry out his job.

In addition, it is found that the level of principal leadership tendency is still classified as moderate (68 87), namely as much as $63.380 \%$. This shows that the leadership of the principal still needs to be improved. When the teacher can do their job well, it will foster their enthusiasm for work. Teachers will feel 
comfortable and eager to work because of their motivation. With the leadership of the principal, teachers are willing, able, and able to properly and successfully complete work assignments under their authority and responsibility. Meanwhile, job skills are skills that are related to work tasks, which are owned and used by the teacher to carry out work assignments that become their authority and responsibility, at the right time.

\section{Work motivation has a direct effect on teacher performance}

The research findings show that work motivation has a direct effect of $4.0 \%$ on teacher performance. The influence that work motivation has on teacher performance comes from the components of motives, expectations, and incentives. In this case the motive contributes $27.207 \%$ to work motivation. Expectations contribute $38.508 \%$ to work motivation. Meanwhile, incentives contribute $34.286 \%$ to work motivation. Based on these results, the work motivation variable is more influenced by the work expectancy component. The expectations a teacher wants determine his work motivation at school. In this case, the expectations a teacher wants to achieve improve teacher performance. The results of this study support the theory put forward by Colquitt (2009: 8) that a person's work motivation has an influence on their performance in the organization. The results of this study also support Darna's (2010) research that achievement motivation has an influence on employee performance.

Work motivation is an encouragement for teachers both from within and from outside themselves to continue to work as well as possible to achieve their goals in work. Every activity carried out by humans is based on a certain motivation. This motivation moves people to achieve something they want. If this motivation is high, then the energy it produces is high. Conversely, if the motivation is low, then the energy it produces is low too. The source of a person's work motivation varies, because no human being is the same as one another. But the most important thing is that with the motivation he has, that person will have more resistance and strength to achieve what he wants.

In addition, the level of work motivation tendency is still classified as moderate (66-84), namely as much as $73.239 \%$. This shows that work motivation still needs to be improved. For a teacher who works in an organization, motivation to achieve organizational goals will make him eager to carry out his job. If the teacher is enthusiastic about working, then their performance will increase. In addition, the teacher's desire to achieve the predetermined performance will be formed.

The model suitability test is intended to test whether the proposed model has a fit with the data or not. From the calculation results obtained $\chi$ observe $=0$. The result $=0$ was consulted with $\chi$ table for $\mathrm{d}=1$ which is 3.68. Thus $\chi$ observe $<\chi$ table $(0>3.68)$, it is concluded that the path analysis model as a whole is significant. This indicates that the proposed model is acceptable. Based on the path coefficient values obtained from the calculation results, the path diagram can be drawn in the Figure 1.

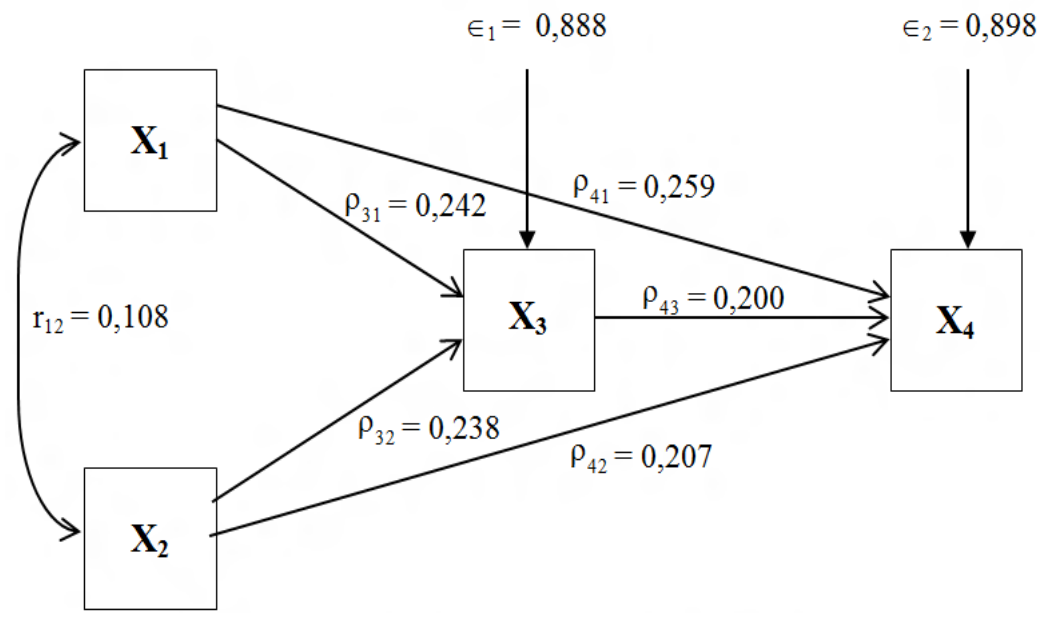

Figure 1. Research Path Diagram

\section{Conclusion}

Based on the study results of obstained in this study are:

1. Pedagogic competence has a direct effect on the work motivation of public elementary school teachers in Medan, meaning that the better the pedagogical competence, the better the work motivation of public elementary school teachers in Medan City.

2. The leadership of the principal has a direct effect on the work motivation of public elementary school teachers in Medan, meaning that the better the leadership of the principal, the better the work motivation of public elementary school teachers in Medan. 
3. Pedagogic competence has a direct effect on the performance of public elementary school teachers in Medan, meaning that the better the pedagogical competence, the better the performance of public elementary school teachers in Medan City.

4. Principal leadership has a direct effect on the performance of public elementary school teachers in Medan City, meaning that the better the leadership of the principal, the better the performance of public elementary school teachers in Medan City.

5. Work motivation has a direct effect on the performance of public elementary school teachers in Medan City, meaning that the better the work motivation, the better the performance of public elementary school teachers in Medan City.

\section{Recommendations}

Based on the research findings, suggestions are made: (1) To the Education Office Medan City. The institution that supervises and ensures the implementation of quality education service processes is recommended: (a) establishing teacher MGMP in target schools to improve teacher performance. The establishment of the MGMP will help teachers to regularly meet and share information related to learning; (b) holding workshops to improve teacher teaching abilities. The form of workshops that must be carried out are: workshops on the use of interactive learning media; and (c) supervise all teachers appropriately and measurably according to teacher weaknesses in teaching in the classroom, such as: analyzing and describing the weaknesses of teachers teaching in class, discussing with teachers and education experts to overcome teacher weaknesses using innovative and fun learning media. To the Principal. The principal can take the findings of this research into consideration in optimizing teacher performance. It is suggested: (a) hold regular workshops to ensure the teaching ability of teachers is always competent, such as: contextual and fun learning workshop activities by utilizing the school environment and making learning media workshops innovative; (b) conducting routine supervision to see and measure the readiness of teachers to use creative innovative teaching methods in the classroom, such as: requiring teachers to use color image media and requiring teachers to utilize instructional videos provided by the school; and (c) encourage teachers to actively participate in seminars outside of school, such as: providing information on teacher training activities, providing compensation for activities for teachers, giving appreciation money and award certificates for outstanding teachers in teaching skills competitions.

\section{Acknowledgement}

The authors would like to thanks to the people who have been instrumental in their assistance and the successful completion of this study.

\section{Author's Contribution}

All authors discussed the result and contributed to from the start to final manuscript.

\section{Conflict of Interest}

The authors declare that they have no competing interests.

\section{References}

Bafadal, I. (2006). Manajemen Peningkatan Mutu Sekolah Dasar dari Sentralisasi Menuju Disentralisasi. Jakarta: Bumi Aksara Brich, P. (2001). Latihan Praktis, Efektif, Motivasi, Instant Leadership. Jakarta: Erlangga.

Colquitt, J. A., Jeffery, A. LePine \& Michael, J. Wesson. (2015). Organizational Behaviour. New York: McGraw-Hill International Companies.

Darna, N. (2010). Pengaruh Penilaian Kinerja terhadap Motivasi Berprestasi dan Kinerja Karyawan. Cakrawala Galuh, Vol. I, No. 3.

Gibson, J. I. Ivanevihch, J.M. dan Donelly, J.H. (2007). Perilaku, Struktur, Proses. Alih Bahasa Nunuk Adiarni. Jakarta: Erlangga.

Hambali, H., Zainuddin, Z., \& Darwin, D. (2020). The Influence of Self-Determination, Organizational Culture, Work Motivation, and Job Satisfaction on the Performance of Principals of State Primary School in Aceh Besar District, Aceh. International Journal for Educational and Vocational Studies, 2(12).

Handoko, T. \& Hani. (2007). Manajemen Personalia dan Sumber Daya Manusia. Yogyakarta: BPFE UGM.

Hoy, W.K. \& Miskel, C.G. (2001). Educational Administration: Theory, Research, and Practice. New York: McGraw-Hill 
Irawati, A \& Sudarsono, B. (2010). Pengaruh Gaya Kepemimpinan terhadap Kepuasan Kerja, Produktivitas Kerja, dan Kinerja Organisasi. Jurnal Studi Manajemen, Vol. 4, No. 1.

Kristiani, W., Matin, M., \& Sugiarto, S. (2019). The Effect of Organizational Culture and Perceived Organizational Support (POS) Towards Organizational Citizenship Behavior (OCB) Teacher SDK PENABUR Jakarta. International Journal for Educational and Vocational Studies, 1(6), 528-532.

Lutfah, A., Hariyati, N., \& Handayaningrum, W. (2019). Improved Teacher Performance Through Work Culture And Environment. International Journal for Educational and Vocational Studies, 1(8), 859-863.

Mashari, A., \& Umami, I. (2019). The Contribution of Teachers' Motivation and Characteristics on the Teachers' Performance in Junior High School of Maarif Metro Lampung. International Journal for Educational and Vocational Studies, 1(6), 599-603.

Pidarta, I Made. (2004). Manajemen Pendidikan Indonesia. Jakarta: Rineka Cipta.

Priansa, D. J. (2014). Kinerja dan Profesionalisme Guru. Bandung: Alfabeta.

Puspandhani, M. E., Fadila, E., \& Shintami, R. A. (2020). The Role of Leadership With the Implementation of Patient Safety in Public Health Center Y in Cirebon City. International Journal for Educational and Vocational Studies, 2(7).

Rahayu, B., Idris, F., \& Herawati, T. (2019). Effect of Principal's Transformational Leadership Style on Teacher Performance. International Journal for Educational and Vocational Studies, 1(5), 392-395.

Rahman, Z., Rijanto, T., Basuki, I., \& Sumbawati, M. S. (2020). The Implementation of Blended Learning Model on Motivation and Students' Learning Achievement. International Journal for Educational and Vocational Studies, 2(9).

Ridlo, M. R., Widodo, S. E., \& Elianasari, E. (2020). The Effect of Power and Motivation in Teacher Organizational Citizenship Behavior (OCB) at Madrasah Aliyah in Central Lombok District. International Journal for Educational and Vocational Studies, 2(2).

Riduwan. (2008). Belajar Mudah Penelitian: Untuk Pegawai-Karyawan dan Peneliti Pemula. Bandung: Alfabeta

Samson, L. (2006). Pengaruh Kepemimpinan dan Motivasi Berprestasi terhadap Kinerja Karyawan PDAM di Kota Ambon". Jurnal Aplikasi Manajemen, Volume 4, Nomor 2.

Setiawan, A., Rusdinal, R., \& Yahya, Y. (2020). Contribution of Teacher Compensation and Teacher Commitment to State Elementary School Teacher Performance In The District of Batang Cenaku Indragiri Hulu District. International Journal for Educational and Vocational Studies, 2(4).

Siagian, F., \& Sirait, J. E. (2019). The Influence of Director Leadership on Improvement of Creativeness Education Manpower, Productivity of Employee Education and Learning Success Students in Cirebon Maritime Academy. International Journal for Educational and Vocational Studies, 1(6), 533-538.

Simorangkir, S. T., Karnati, N., \& Abdullah, T. (2019). The Effect of Supportive Leadership, Learning Culture, and Responsibility on Job Performance of Teacher in Junior High Schools of South Tangerang. International Journal for Educational and Vocational Studies, 1(2), 120-129.

Siwantara, I. W. (2009). Pengaruh Kompetensi Profesional dan Motivasi Kerja Serta Iklim Organisasi terhadap Disiplin Kerja dan Kinerja Dosen Politeknik Negeri Bali. Ragam, Vol. 9, No. 2.

Sriwidodo, U. \& Sugito, B. (2007). Pengaruh Kepemimpinan, Kepercayaan, dan Kepuasan Kerja terhadap Kinerja Karyawan. Jurnal Manajemen Sumberdaya Manusia, Vol. 2 No. 1.

Stoner, JAF. (1992). Management. New Jersey: Prentice Hall.

Tanjung, A., Giatman, G., Ambiyar, A., \& Syahril, S. (2020). Influence of Leadership Orientation and Level of Awards Against Employee Loyalty in Lancang Kuning University. International Journal for Educational and Vocational Studies, 2(6).

Thoha, M. (2004). Perilaku Organisasi. Jakarta: Raja Grafindo Persada.

Wahyuningtyas, E. P., Handayaningrum, W., \& Wuryani, E. (2020). The Evaluation of Teachers' Performance in Terms of Pedagogic Competence and Professional Competence in Unesa Labschool Junior High School. International Journal for Educational and Vocational Studies, 2(3).

Winardi, J. (2002). Manajemen Perilaku Organisasi. Jakarta: Kencana Prenada Media Group. 